\title{
VERSOS DE SEBASTIÁN DE HOROZCO NO INCLUIDOS EN LA EDICIÓN DE SU CANCIONERO
}

Ofrecemos aquí versos de tres poesías de Sebastián de Horozco (21510?-1580) no incluidos en la edición de su Cancionero (Sociedad de Bibliófilos Andaluces, Sevilla, 1874), quizá por demasiado verdes o "sucios". Todos estos versos, sin embargo, se imprimieron fielmente en una hoja suelta, destinada con toda probabilidad a un grupo muy selecto de suscriptores, e intitulada "Versos suprimidos en las páginas 26 y 29 de este Cancionero" 1 . La tirada de esta hoja suelta debe haber sido limitadísima. No hay indicaciones de ella en catálogos como el de la B.N.P. o los de las bibliotecas del British Museum y del Congreso de Washington. Tampoco la citan Palau ni Simón Díaz. En cambio, la H.S.A. tiene dos ejemplares, que son los únicos de que tenemos noticia ${ }^{2}$

La tercera de las poesías que aquí publicamos ("Reçepta que embió el auctor...") figura en el Cancionero moderno de obras alegres ${ }^{3}$, adonde pasó seguramente de la hoja suelta que acabamos de mencionar. El Cancionero, a su vez, sirvió como fuente para el reciente Diccionario secreto de Cela4.

Para Menéndez Pelayo, la obra de Horozco "traspasa la raya del decoro" muy a menudo . Sin embargo, es evidente que la comprensión de este aspecto nos ayudará a entender mejor una época en que aparecieron no pocas obras de índole semejante, como el Cancionero de obras de burlas provocantes a risa (1519) y La Lozana andaluza (1528).

Nuestra edición se basa en el ms. del Cancionero de Horozco, conservado en la Biblioteca Capitular y Colombina de Sevilla, a cuyas autoridades expresamos nuestro agradecimiento por haber concedido licencia de publicarlos. Subrayamos los versos omitidos en la ed. de Bibliófilos e indicamos la página de esta edición y el folio del ms.

Northern Illinois University.

JACK WEINER

1 Datos que debo a la gentileza de Theodore S. Beardsley, director de la H.S.A. (carta del 19 de julio de 1971).

2 Catalogue général des liures imprimés de la Bibliothèque Nationale, t. 73, Paris, 1929, p. 879; British Museum, General catalogue of printed books, t. 219, London, 1964, p. 670; Library of Congress, Catalogue of printed cards, t. 70, [Washington], 1943, p. 264; Antonio Palau y Dulcet, Manual del librero hispano-americano, 2a ed., t. 6, Barcelona, I953, p. 649; JosÉ SIMón DíAz, Bibliografía de la literatura hispánica, Madrid, 1960- (en curso de publicación); The Hispanic Society of America, Catalogue of the Library, Boston, 1962, t. 5, p. 4548.

3 Cancionero moderno de obras alegres, ed. H. W. Spiritual, Sevilla, 1875 (Londres, 1876), p. 107. (En las pp. 108-112 de este Cancionero hay otra poesía de Horozco, ésta sf incluida totalmente en la edición de Bibliófilos, pp. 34-36) .

4 Camilo José Cela, Diccionario secreto, t. I, Madrid-Barcelona, 1968, pp. 56 y 254.

5 Marcelino Menéndez Pelayo, Obras, ed. nacional, t. 16, Madrid, 1962, p. 92. 
"El auctor a unas monjas sus devotas" (ed., p. 26; ms., fol. 12v).

Las que estáis en religión muy castas y continentes, suplicôs que con perdón me soltéis una questión que se me viene a las mientes, porque no soy adivino ni alcanço vuestros primores, $y$ es que pues crece contino, ¿qué hazéis del vellocino de las partes inferiores?
Porque si no lo cortáis respondedme dónde os llega, pero si le desmontáis, dezidme si deseáis aquello que se os deniega, y si vuestro coraçón, remirando aquella alhaja, siente que aquel boquerón no estava alli sin razón ni fue para encerrar paja.

"El auctor a otra que bivía desonestamente" (ed., pp. 28-29; ms., fol. 13v).

Según sois tan visitada, bien será que paséis vanco, pues que de vuestra posada nunca negasteis la entrada a ningún negro ni blanco. Dizenme que de afirmar tenéis rozados los codos, tanto, que ya dais lugar a que no os saben llamar sino marica de todos.

Hecha estáis siempre terreno blanqueando el albayalde, dando vuestro delantero a los moros por dinero y a los xprianos de balde. Porque de tan liberal no miráis en poquedades, $y$ vuestro mejor caudal es ser gentil orinal de dos mil frayles y abades.
$\mathrm{Y}$ mientras tenéis salud y no tenéis quién os ladre, con toda solicitud os dais bien a la virtud por l'alma de vuestro padre. Pero como sois tan moça de más de cinqüenta y dos, mantenéis a toda broça cavalgar y ande la loça, que para todo ay en vos.

Yo salgo por fiador, como os veo de tal arte, que por bondad ni temor nunca falte el obrador por vos ni de vuestra parte. Vuestra desonestidad será causa, aunque me tardo, de hazer con brevedad que vais de la vezindad a vivir a San Leonardo.

"Reçepta que embió el auctor a una dama que deseava enpreñarse" (ed., p. 29; ms., fols. $13 \mathrm{v}-14 \mathrm{r}$ ).

Si os queréis hazer preñada, tomad sin que se publique canahoria encañutada con çumo de riñonada, sacado por alambique. Ante noche y de mañana lo tomad con devoción, y aun cada vez que ayáis gana, porque esta cosa es tan sana que siempre tiene sazón.
$Y$ mientras aquesto dura hazed siempre movimiento, y si no obra natura, mudaréis cabalgadura que sea más a contento. No os dará ninguna pena, antes plazer $y$ sabor, y esta reçepta es tan buena, que ni Hipocrás ni Aviçena os la podrié dar mejor. 


\section{Doctrinade Epitétio.}

Fraducida por

Don Franciscs or Ferededo villogas.

\section{Cope. \&.}

Lar cosas exiterior, interiormenta

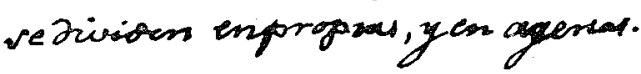
Lo gue erta en nuestra mano inteperideste son la opinton, y el fuicis or las coras: sequir, yprocurar tapproveshovas: Inviri y aborrecer las fterosisuas; yporgue on un precepto to percitar, quantas acciones semos, yue llamor muestras coneralo pademos. 2..... No ertan en nuertiva mamo el cuerpo, ta tacienda, rec elprofono bomor, las zigentabe, ylor prentos, (igualmente crocisias, $y$ molestor) y alfien tod as las cosas, gue opetcoer sepucher,

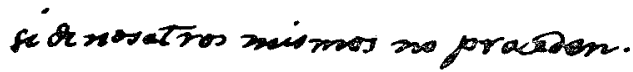

